\title{
Santuza Cambraia Naves (1952-2012) In Memoriam
}

\section{Dulce Chaves Pandolfi}

“Como definir a 'canção crítica'? Poderíamos recorrer primeiramente a um recorte temporal, situando-a no final dos anos 50 e ao longo dos 60. Década de 1960 em diante: os compositores passaram a comentar todos os aspectos da vida, do político ao cultural, tornando-se 'formadores de opinião'. Na medida em que a canção popular, no Brasil, desenvolveu um estatuto peculiar, tornando-se um lócus para onde passaram a confluir informações de diversas áreas, artísticas, culturais e políticas, o compositor criou a identidade de intelectual, num sentido mais amplo do termo. A canção popular tornou-se assim o veículo por excelência do debate intelectual, tanto com relação a questões textuais quanto a problemas contextuais. Por um lado, o compositor, como é comum ocorrer com o artista 'moderno', passou a atuar como crítico no próprio processo de composição da canção. Por outro, a crítica também era dirigida aos fatos culturais e políticos do país, de maneira congruente com a proposta destes compositores de articular arte e vida. O compositor popular tornou-se um crítico. Ao operar criticamente no processo de composição, o compositor popular fez uso da metalinguagem, da intertextualidade e de outros procedimentos que remetem a diversas formas de citação, como a paródia e o pastiche. E ao estender a atitude crítica 
para além dos aspectos formais da canção, o compositor popular tornou-se um pensador da cultura."

Neste texto, ou melhor, nestas anotações para arguição de uma banca de doutorado reunida no dia 30 de março de 2012 na Universidade Federal Fluminense, cinco dias antes da sua morte, Santuza Cambraia Naves sintetizou o conceito de "canção crítica", que vinha desenvolvendo nos últimos anos da sua densa produção intelectual.

Mineira de Boa Esperança, Santuza nasceu no dia 19 de maio de 1952. Foi em Minas que passou os vinte primeiros anos da sua vida, viveu suas primeiras paixões, ouviu e cantou as primeiras canções. Em 1973 Santuza foi morar em Brasília, quando Antonio Carlos Ribeiro, Tonico, então seu marido e pai dos seus dois filhos Felipe e Júlio, funcionário do Ministério da Fazenda, foi transferido para a capital federal. Em Brasília, segundo costumava contar, fascinada com as aulas de Sociologia a que assistiu na UnB com as professoras Barbara Freitag e Regina Morel, transferiu-se do curso de Direito que havia iniciado em Varginha, cidade vizinha de Boa Esperança, para o de Ciências Sociais.

Em meados de 1979, recém-formada, Santuza veio morar no Rio, onde ficou para sempre. Nos primeiros anos no Rio, fez muita coisa. Ajudou a criar a Associação Profissional dos Sociólogos do Rio de Janeiro, a APSERJ, participou da construção do Partido dos Trabalhadores, fazia condução escolar para crianças que estudavam no mesmo colégio dos seus filhos, foi pesquisadora em Projeto da Funarte sobre a produção cultural brasileira dos anos 1970, escreveu muitas resenhas sobre livros de Ciência Política para o caderno Livro do Fornal do Brasil, trabalhou como pesquisadora no Arquivo Nacional. Além disso tudo, depois que se separou do Tonico, apaixonada pela música popular brasileira, dona de uma voz especial e de um sorriso solar, quase se tornou cantora profissional.

Em 1983 iniciou o mestrado em Antropologia no Museu Nacional. Foi aí que, de forma criativa e inovadora, juntou a música, sua grande e antiga paixão, com a Antropologia, sua nova paixão. Sob a orientação de Gilberto Velho, conseguiu fazer da obra de Caetano Veloso "o objeto identificado" da sua dissertação de mestrado.

Em 1986, ainda durante a fase do Museu Nacional, Santuza conheceu o poeta e tradutor Paulo Henriques Britto. Amor de sua vida, companheiro de jornada, Paulo foi mais tarde também um parceiro intelectual pois, com temas literários e interesses comuns, pesquisaram e publicaram juntos.

Em seu percurso, estudiosa do Modernismo, muito especialmente dos escritos de Oswald e Mario de Andrade, Santuza entrou de corpo e alma nos embates sobre a Bossa Nova e a Tropicália, sobre as fronteiras entre a música erudita e a música popular. Em 1991, iniciou o doutorado em Sociologia no Instituto 
Universitário de Pesquisas do Rio de Janeiro, IUPERJ, sob a orientação de Ricardo Benzaquen de Araújo, e pouco depois defendeu sua tese de doutorado, $O$ violão azul, que foi publicada pela Editora da Fundação Getulio Vargas.

Além de dedicar-se às suas próprias pesquisas, Santuza ajudou a coletar e organizar uma rica documentação sobre música no Centro de Estudos Sociais Aplicados da Universidade Candido Mendes, CESAP, onde fundou o Núcleo de Estudos Musicais e trabalhou por mais de dez anos.

E, assim, por estes caminhos, Santuza foi construindo seu "nicho": tornou-se referência obrigatória para quem quisesse estudar música popular brasileira. Publicou dezenas de artigos em revistas acadêmicas nacionais e internacionais, escreveu ou organizou outros tantos livros, entre eles Da Bossa Nova à Tropicália, A MPB em discussão - entrevistas, Velô e Canção popular no Brasil. Intelectualmente muito produtiva e irrequieta, fez estudos sobre as contraculturas, a música eletrônica, o hip hop e outras formas de expressão musical. Mais recentemente estava buscando entender o impacto das novas tecnologias na mudança da produção musical.

No dia seguinte da sua morte, José Miguel Wisnik, compositor e professor de Literatura Brasileira da USP, deu a seguinte declaração para a Folha de São Paulo: "Santuza acompanhou a música popular brasileira nas suas várias frentes, de maneira viva, generosa, atenta, inteligente. Abriu frentes de pesquisa, reuniu pessoas, soube extrair dos artistas os seus melhores depoimentos." Também nesse mesmo dia escreveu Frederico Coelho, seu parceiro e professor de Literatura Brasileira e Artes Cênicas da PUC-Rio: "O pensamento e os temas trabalhados por Santuza são solares, pois nos apresentam o que de mais potente se produziu em uma determinada época da arte brasileira. (...) Santuza ficará ressoando entre nós por muitos e muitos anos quando falarmos sobre a música popular brasileira de ontem, de hoje e de além".

Mas, além de ser reconhecida como pesquisadora nata, Santuza era também uma professora "por vocação". O início foi na Candido Mendes em 1988, seguido de uma rápida passagem na UERJ, mas foi na PUC, onde ingressou em 1994, que fez uma exemplar carreira docente. Foi admirada não só pela presença na sala de aula, mas como orientadora e interlocutora de alunos e colegas do seu departamento e de outros departamentos daquela universidade.

Como afirmou Santuza, naquelas mesmas anotações redigidas para a arguição de uma tese de doutorado cinco dias antes de sua morte, "como nenhuma sociedade se funda sem valores, eu, como nativa, tenho os meus, e, como antropóloga, procuro lidar com eles. Compartilho com Max Weber a idéia de que seria impossível exercer a atividade de cientista social abrindo mão da subjetividade (impregnada de valores). E com Edward Sapir, compartilho a perspectiva nietzscheana de que não deveríamos reproduzir passivamen- 
te o legado cultural de nossos ancestrais, mas promover escolhas com relação aos repertórios herdados da tradição (...)".

Cientista social também por vocação e com valores, Santuza fez suas escolhas na arte e na vida. Entre tais escolhas estavam alguns artistas que, segundo suas próprias palavras, "por meio de um artesanato musical acima do seu tempo, se tornaram protagonistas importantes no cenário cultural a partir dos anos 60 ". Segundo ela, "Chico e Caetano se notabilizaram não exatamente pelo teor de suas letras ou de seus discursos, mas pela magistralidade de suas canções”. Plagiando um pouco a própria Santuza, eu diria que ela se notabilizou não só pela qualidade de seus escritos e de suas aulas, mas, sobretudo, pela magistralidade da sua vida, ou seja, pelo "conjunto da obra". 